\title{
Weak up-regulation of serum response factor in gastric ulcers in patients with co-morbidities is associated with increased risk of recurrent bleeding
}

\author{
Hsiu-Chi Cheng ${ }^{1,2}$, Hsiao-Bai Yang ${ }^{3,4}$, Wei-Lun Chang ${ }^{1,2}$, Yi-Chun Yeh ${ }^{1,5}$, Yu-Ching Tsai ${ }^{1}$, Bor-Shyang Sheu ${ }^{1,2^{*}}$
}

\begin{abstract}
Background: Serum response factor (SRF) is crucial for gastric ulcer healing process. The study determined if gastric ulcer tissues up-regulate SRF and if such up-regulation correlated with co-morbidities and the risk of recurrent bleeding.
\end{abstract}

Methods: Ulcer and non-ulcer tissues were obtained from 142 patients with active gastric ulcers for SRF expression assessed by immunohistochemistry. Based on the degree of SRF expression between these two tissue types, SRF up-regulation was classified as strong, intermediate, and weak patterns. The patients were followed-up to determine if SRF up-regulation correlated to recurrent bleeding.

Results: Gastric ulcer tissues had higher SRF expression than non-ulcer tissues $(p<0.05)$. Patients with strong SRF up-regulation had lower rates of stigmata of recent hemorrhage (SRH) on the ulcer base than the others $(p<0.05)$. Multivariate logistic regression confirmed that co-morbidities and weak SRF up-regulation were two independent factors of recurrent gastric ulcer bleeding $(p<0.05)$. Combining both factors, there was an 8.29 -fold $(95 \% \mathrm{Cl}$, 1.31 52.62; $p=0.03$ ) higher risk of recurrent gastric ulcer bleeding.

Conclusions: SRF expression is higher in gastric ulcer tissues than in non-ulcer tissues. Weak SRF up-regulation, combined with the presence of co-morbidities, increase the risk of the recurrent gastric ulcer bleeding.

\section{Background}

Peptic ulcer bleeding is a common and potentially lethal disease with mortality rates as high as $8-10 \%$. The high mortality is accounted for by senility, etiology, severity of bleeding, co-morbidities, and the presence of stigmata of recent hemorrhage (SRH) [1]. $\mathrm{SRH}$ is a classical clinical assessment that predicts the development of recurrent peptic ulcer bleeding if the fading time of SRH is $4.1 \pm 2.1$ days after first bleed $[2,3]$. However, patients with co-morbid illnesses are prone not only to having poor ulcer healing but also to delayed recurrent bleeding [4-7]. For patients at risk, it is necessary to validate the possible molecule mechanisms related to ulcer healing.

Serum Response Factor (SRF), a transcription factor protein, binds to serum response elements to control

\footnotetext{
* Correspondence: sheubs@mail.ncku.edu.tw

'Institute of Clinical Medicine, Medical College, National Cheng Kung

University, Sheng Li Road, Tainan, Taiwan

Full list of author information is available at the end of the article
}

particular genes expressions for peptic ulcer healing [8-11]. The healing process of gastric ulcers is complex, requiring the restoration and proliferation of epithelial cells, fibroblasts, macrophages, and endothelial cells [12-15]. SRF reportedly promotes gastric ulcer healing by stimulating the proliferation and differentiation of such cells $[15,16]$. Therefore, it is important to determine the clinical significance of SRF in gastric ulcers healing, especially in patients with SRH and co-morbidities.

This study aimed to determine whether SRF expression in gastric ulcer tissues is higher than that of antral non-ulcer tissues, and if SRF expression in gastric ulcer tissues is related to Helicobacter pylori (H. pylori) infection, non-steroidal anti-inflammatory drugs (NSAID) intake, or others. This study is the first to validate the correlation of SRF up-regulation with the presence of $\mathrm{SRH}$ and determine if it is independently predictive of the recurrent gastric ulcer bleeding. 


\section{Methods}

\section{Patients and study design}

Patients with or without co-morbidities who received upper gastroscopy for melena, hematochezia, or hematemesis and being disclosed gastric ulcers were consecutively enrolled. We enrolled patients with gastric ulcers but not duodenal ulcers because gastric ulcers biopsy is performed according to routine practice at the investigational center. The co-morbidities included congestive heart failure, coronary artery disease, disseminated malignancy, liver cirrhosis, acute renal failure, chronic kidney disease, end-stage renal disease requiring hemodialysis, chronic obstructive pulmonary disease, pneumonia, restrictive lung disease, sepsis, and new onset cerebro-vascular accident.

Patients were excluded if they had tumor bleeding or ulcer bleeding due to mechanical factors (i.e. induction of gastrostomy tube), use of anticoagulant, or failure to establish hemostasis during upper gastroscopy.

The SRH was defined by Forrest et al. [2]. Patients with bleeding gastric ulcers and classified as Forrest classification Ia (arterial bleeding), Ib (oozing bleeding), IIa (nonbleeding visible vessels), IIb (adherent blood clots), to IIc (hematin) of gastric ulcers bleeding were treated by standardized endoscopic injection therapy with diluted epinephrine 1:10000 or normal saline regardless of combined therapy with heater probe, argon plasma coagulation, band ligation, or hemoclip therapy to eradicate the vessel. After hemostasis by endoscopic therapy, patients received an $80 \mathrm{mg}$ bolus injection of intravenous omeprazole (LOSEC, AstraZeneca AB, Södertälje, Sweden), then intravenous omeprazole infusion $8 \mathrm{mg} / \mathrm{h}$ for 3 day. After omeprazole infusion, oral esomeprazole (NEXIUM, AstraZeneca AB) $40 \mathrm{mg}$ daily was given until the end of follow-up.

Gastric mucosal biopsies were performed under direct vision with the Olympus gastroscopy (Olympus GIF-XQ 260 endoscope, Olympus Optical Co. Ltd, Tokyo, Japan) within $12 \mathrm{~h}$ after bleeding. Patients with Forrest classification Ia to IIb of gastric ulcers bleeding underwent second look gastroscopy for gastric mucosal biopsy via standard biopsy forceps (Olympus FB-25K-1) for histology studies three days later. Eight biopsies were taken: six from the ulcer edge as ulcer tissues and two from the antral mucosa that was macroscopically normal, about $2 \mathrm{~cm}$ from the pylori ring and at least $2 \mathrm{~cm}$ from the ulcer, as antral non-ulcer tissues $[17,18]$.

The patients were diagnosed with $H$. pylori infection either by positive rapid urease test (CLO test, KimberlyClark, Draper, Utah, USA) or histology as before [17-19]. NSAID intake was defined as continuous or sporadic intake more than 3 times a week during the past 4 weeks. The ethics committee of National Cheng Kung University,
Taiwan, approved the study design and participants provided informed consent. The institutional review board is "Pathogenic roles and clinical relevance of TGF- $\beta 1$ and SRF in peptic ulcer patients with comorbid illnesses".

\section{Outcome measures}

All of the patients were followed-up as possible until 28 days after the first episode of melena, hematochezia, or hematemesis. The primary end-point was recurrent bleeding within this period. Documented recurrent bleeding should fulfill one of the following conditions: (i) continuous melena, hematochezia, or the presence of recurrent bloody aspirates through the nasogastric tube; and (ii) relapse of hemodynamic instability, including systolic blood pressure $<90 \mathrm{mmHg}$, heart rate $>120$ beats $/ \mathrm{min}$, or hemoglobin drop $>2 \mathrm{~g} / \mathrm{dL}$. We did not perform routine second look endoscopy in the absence of above clinical signs of re-bleeding to avoid misclassification of nonsignificant re-bleeding [20].

\section{Immunohistochemistry Studies for Gastric SRF Expression}

Tissue immune-histochemical staining was performed using monoclonal antibody of SRF (Santa Cruz Biotechnology, Inc. Santa Cruz, CA, USA). The gastric tissue was fixed in $10 \%$ buffered formalin. The specimen was embedded in paraffin, serially sectioned at $4 \mu \mathrm{m}$ thickness, placed onto the microscope slide, and deparaffinized in xylene and dehydrated in a graded series of ethanol. The specimen was immersed for 20 minutes in 3\% hydrogen peroxide to stop endogenous peroxidase activity and antigen retrieval with DakoCytomation Target Retrieval Solution (Dako, Carpinteria, CA, USA). The non-specific binding site was saturated with $2.5 \%$ bovine serum albumin. The tissue section was treated with primary antibody against SRF at a dilution of 1:400 and then incubated overnight in a humidified chamber at $4^{\circ} \mathrm{C}$.

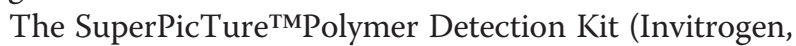
Carlsbad, CA, USA) was adapted for blocking, linkage, and labeling for staining according to the manufacturer's instructions. 3-amino-9-ethylcarbazole was used as the chromogen. The section was then counter-stained with hematoxylin. The colon ulcer tissue was used for positive control.

The same pathologist blinded to the patients' clinical background scored the immune-histochemical staining of SRF. The expression grades of SRF staining were scored semi-quantitatively according to the percentage of superficial epithelial cells or mononuclear cells of the lamina propria positively stained. The score ranged from 0-4 in intensity, listed as 0 (negative), 1 ( $<5 \%$ cells), 2 (5-29\% cells), 3 (30-59\% cells), or 4 ( $\geq 60 \%$ cells) [21,22]. Mucosal smooth muscle cells were graded as 1 (baseline staining in capillary muscle), 2 (increase of inter-glandular muscle), 
and 3 (increase with nuclear staining) (Figure 1). A score $\geq 2$ was defined as high SRF expression with $>5 \%$ cells of the superficial epithelium and mononuclear cells of the lamina propria positively stained, or with positively stained inter-glandular smooth muscle cells. A score $<2$ was defined as low SRF expression.

The net increase of SRF intensity between ulcer tissues and non-ulcer tissues within the same individual was also compared. The net increase of SRF intensity was calculated as SRF intensity of the ulcer tissue minus that of the non-ulcer tissue in the superficial epithelium, mononuclear cells of the lamina propria, and mucosal smooth muscle cells, respectively. Based on the degree of net increase of SRF intensity, SRF up-regulation on ulcer tissues was classified into strong, intermediate, and weak patterns. Strong up-regulation of SRF on ulcer tissues

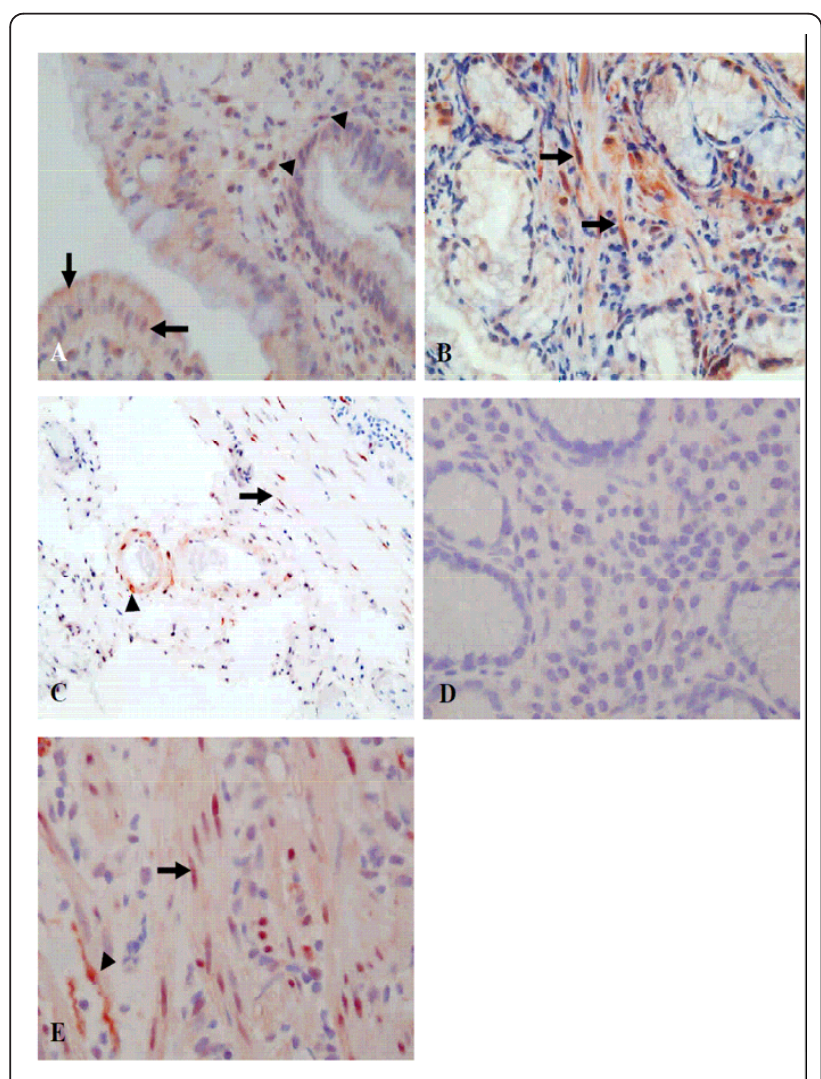

Figure 1 Representative immune-histochemical staining of SRF expression. (A) High nuclear and cytoplasmic SRF intensity of regenerative epithelial cells (arrow), some mononuclear inflammatory cells and myofibroblasts (arrowhead) of the lamina propria in gastric ulcer tissues (Magnification $\times 2400$ ). (B) Increased nuclear and cytoplasmic SRF intensity of smooth muscle cells (arrow) between the deep glands ( $\times 1200$ ). (C) Nuclear staining of SRF in smooth muscle cells of the muscularis mucosa (arrow) and vascular wall (arrowhead) (× 600). (D) Low SRF intensity in non-ulcer tissues $(\times 2400)$. (E) The positive control of colon ulcer tissues indicates positive nuclear staining in smooth muscle cells (arrow) and nerve (arrowhead). was defined as a uniform net-positive increase of SRF intensity over the gastric epithelium, mononuclear cells and muscle cells. In contrast, weak SRF up-regulation on ulcer tissues was defined by the presence of two netnegative increases of SRF intensity compared to nonulcer tissues. The other patterns of SRF net changes were accordingly defined as intermediate up-regulation.

\section{Statistical analysis}

The Student $t$ test, Fisher's exact test, one-way ANOVA and Pearson $\chi^{2}$ test with McNemar's correction were used as appropriate. The Mann-Whitney $U$ test was applied to assess SRF intensity in the different study groups. All of the tests were two-tailed, with $p<0.05$ taken as significant.

\section{Results}

Demographic background of the study patients

From August 2003 to December 2007, 142 patients (58 women and 84 men) with mean age of 66 years and gastric ulcers in the active stage were prospectively consecutively enrolled. Of the 142, 132 (93.0\%) patients' ulcers located on the antrum, others located on the body. Seventy-eight (54.9\%) patients had Forrest classification Ia to IIc SRH, and $94.2 \%$ (49/52) of Ia to IIb SRH were treated with endoscopic hemostatic monotherapy or dual therapy. The etiologies of gastric ulcers included $45 \mathrm{H}$. pylori-infected ulcers, 30 NSAID-related ulcers, 46 H. pylori-infected and NSAID-related ulcers, and 21 other causes induced ulcers.

\section{Gastric ulcer tissues had higher SRF expression than non-ulcer tissues}

SRF was predominantly stained in nuclei or cytoplasm of regenerative superficial epithelium and mononuclear inflammatory cells and myofibroblasts of the lamina propria (Figure 1A and 1B). SRF was also stained in nuclei of smooth muscle cells of the muscularis mucosa and vascular wall (Figure 1C). The rates of high SRF expression were significantly higher in ulcer tissues (Figure 1A) than in non-ulcer tissues (Figure 1D), including the superficial epithelium $(54.2 \%$ vs. $30.3 \%$, $p<0.01)$, mononuclear cells of the lamina propria (69\% vs. $58.5 \%, p=0.021$ ), and mucosal smooth muscle cells (80\% vs. $68.1 \%, p=0.024)$ (Table 1). Moreover, for both ulcer and non-ulcer tissues, the rates of high SRF intensity on mucosal smooth muscle cells or mononuclear cells of the lamina propria were higher than those on the superficial epithelium $(p<0.01)$.

\section{Factors related to up-regulation of SRF intensity on gastric ulcer}

Based on the degree of the net increase of SRF intensity, SRF up-regulation were classified into strong $(\mathrm{n}=18)$, 
Table 1 Gastric ulcer tissues had higher SRF intensity than non-ulcer tissues

\begin{tabular}{|c|c|c|c|}
\hline \multirow[t]{2}{*}{ Gastric histology $(n=142)$} & \multicolumn{2}{|c|}{ High SRF intensity (n, \%) } & \multirow[t]{2}{*}{$P$ value $^{t}$} \\
\hline & Ulcer & Non-ulcer & \\
\hline Superficial epithelium & $77(54.2 \%)$ & $43(30.3 \%)$ & $<0.01$ \\
\hline Mononuclear cells of the lamina propria & $98(69.0 \%)$ & $83(58.5 \%)$ & 0.021 \\
\hline Mucosal smooth muscle cells & $112(80.0 \%)$ & $96(68.1 \%)$ & 0.024 \\
\hline$P$ value & $<0.01^{\neq, \S}, 0.035 q$ & $<0.01^{ \pm, \S}, 0.067 \rrbracket$ & \\
\hline
\end{tabular}

${ }^{\dagger} P$ values indicated the significant difference of the rates of the high SRF intensity on ulcer tissues as compared with antral non-ulcer tissues (by McNemar's test). ${ }^{\ddagger}$ Superficial epithelium vs. mononuclear cells of the lamina propria. ${ }^{\S}$ Superficial epithelium vs. mucosal smooth muscle cells. १Mononuclear cells of the lamina propria vs. mucosal smooth muscle cells. SRF: serum response factor.

intermediate $(n=83)$, and weak $(n=41)$ patterns. The most impressive finding was that patients with strong up-regulation of SRF intensity had lower rate of Forrest classification Ia to IIc SRH than patients with either intermediate or weak SRF up-regulation $(p<0.05)$ and had a trend of less co-morbid illness $(p=0.14)$. Nonetheless, there were no differences in age, ulcer size, endoscopic hemostatic therapy, mean hemoglobin, platelet counts, percentage of hypo-albuminemia $<3 \mathrm{~g} / \mathrm{dL}$, and serum creatinine $\geq 1.5 \mathrm{mg} / \mathrm{dL}$ among these patients with different degrees of SRF up-regulation $(p>0.05$, Table 2). However, SRF intensities were similar between patients with serum albumin $<3.0$ and those with $\geq 3.0 \mathrm{~g} / \mathrm{dL}(p>0.05)$.

There were no differences in $H$. pylori infection or NSAID use among patients with different degrees of SRF up-regulations $(p>0.05)$ (Table 2$)$. The rates of high SRF intensity of gastric ulcers were similar among patients with $H$. pylori-infected ulcers, NSAID-related ulcers, or $H$. pylori-infected and NSAID-related ulcers $(p>0.05)$ (Figure 2).

\section{Weak SRF up-regulation independently related with recurrent gastric ulcer bleeding}

Underlying medical co-morbidity and the presence of weak SRF up-regulation on ulcer tissues were not only significant univariate factors (Table $3, p<0.05$ ) but also independent risk factors of recurrent bleeding $(p<$ $0.05)$. Age $\geq 60$ years, $H$. pylori infection, or NSAID use were not risk factors of recurrent bleeding $(p>0.05)$. The recurrent bleeding rates of gastric ulcers increased stepwise from $0 \%$ in non-co-morbid patients without weak SRF up-regulation, $1.9 \%$ in co-morbid patients without weak SRF up-regulation to $5.9 \%$ in non-comorbid patients with weak SRF up-regulation and up to $12.5 \%$ in co-morbid patients with weak SRF up-regulation $(p=0.006)$ (Figure 3$)$. Combining both factors, the risk of recurrent gastric ulcer bleeding in co-morbid patients with weak SRF up-regulation increased by 8.29 fold (95\% CI, 1.31 52.62; $p=0.03$ ).

The rates of weak SRF up-regulation on gastric ulcers increased in a trend of patients with neither recurrent bleeding nor co-morbidity, without recurrent bleeding

Table 2 Demographic and clinical parameters correlated with different degrees of SRF up-regulation on gastric ulcers

\begin{tabular}{|c|c|c|c|c|}
\hline Up-regulation of SRF & $\begin{array}{l}\text { Strong } \\
(n=18)\end{array}$ & $\begin{array}{l}\text { Intermediate } \\
\quad(\mathrm{n}=83)\end{array}$ & $\begin{array}{c}\text { Weak } \\
(n=41)\end{array}$ & $\begin{array}{c}P \\
\text { value }^{\dagger}\end{array}$ \\
\hline Female: Male & $7: 11$ & $29: 54$ & $22: 19$ & 0.13 \\
\hline Mean age $(y r)$ & 62.3 & 66.4 & 67.0 & 0.53 \\
\hline \multicolumn{5}{|l|}{ Ulcer characteristics ( $n$ ) } \\
\hline SRH, Forrest classification la to IIC (\%) & 22.2 & 61.4 & 58.5 & 0.01 \\
\hline Mean ulcer size $(\mathrm{cm})$ & 1.51 & 1.47 & 1.70 & 0.65 \\
\hline Endoscopic hemostatic therapy in patients with Forrest classification la to IIb SRH (\%) & 100 & 91.9 & 100 & 0.52 \\
\hline H. pylori infection (\%) & 61.1 & 62.7 & 68.3 & 0.80 \\
\hline NSAID user (\%) & 55.6 & 50.6 & 58.5 & 0.70 \\
\hline Comorbidity (\%) & 33.3 & 57.8 & 58.5 & 0.14 \\
\hline Mean $\mathrm{Hb}(\mathrm{g} / \mathrm{dL})^{\ddagger}$ & 10.2 & 10.0 & 9.6 & 0.71 \\
\hline Platelet $\left(\mathrm{mm}^{3}\right)^{\ddagger}$ & 300.4 & 244.7 & 247.3 & 0.24 \\
\hline Serum albumin $<3 \mathrm{~g} / \mathrm{dL}(\%)^{\ddagger}$ & 37.5 & 26.4 & 36.0 & 0.62 \\
\hline Serum Creatinine $\geq 1.5 \mathrm{mg} / \mathrm{dL}(\%)^{\ddagger}$ & 20.0 & 26.3 & 33.3 & 0.58 \\
\hline
\end{tabular}

Up-regulation of SRF indicated the distribution of net-positive increase of SRF intensity in ulcer tissues than in non-ulcer tissues of superficial epithelium, mononuclear cells of the lamina propria, and mucosal smooth muscle cells, respectively. SRF: serum response factor; SRH: stigmata of recent hemorrhage; H. pylori: Helicobacter pylori; NSAID: non-steroidal anti-inflammatory drugs; $\mathrm{Hb}$ : hemoglobin. ${ }^{\dagger}$ One-way ANOVA and Pearson $\chi^{2}$ test were used as appropriate. ${ }^{\ddagger}$ Reference range: Hb level, 13.5-17 g/dL; platelet count; $138.1-353.4 \times 10^{3} / \mathrm{cmm}$; serum albumin level, 3.5-5 g/dL; serum creatinine, 0.7-1.5 mg/dL. 


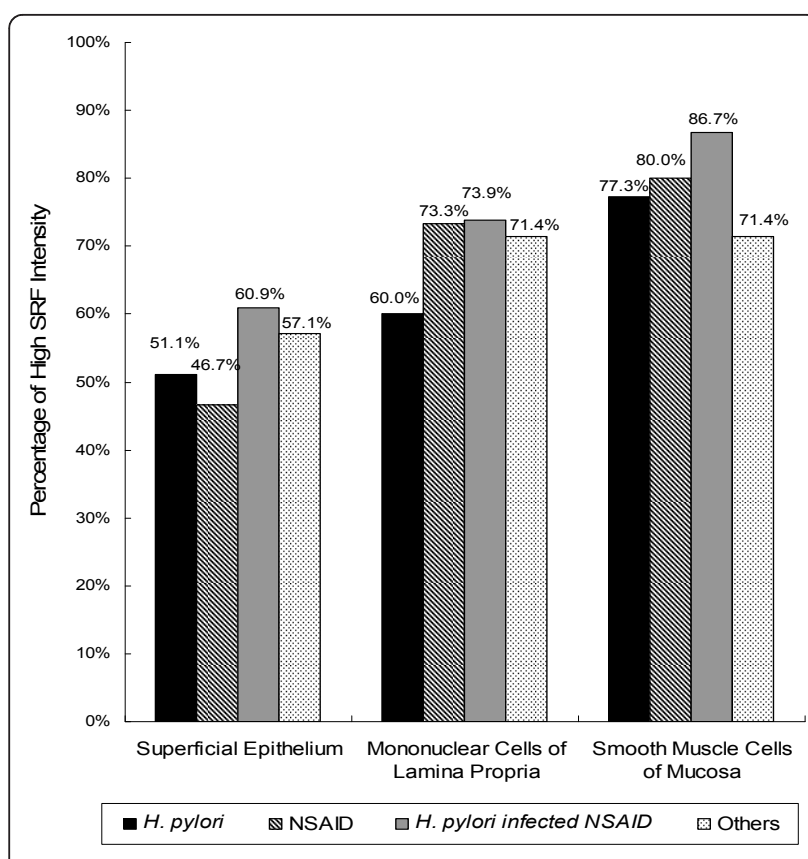

Figure 2 Percentages of high SRF intensity of gastric ulcers among patients with different etiologies. The rates of high SRF intensity of gastric ulcers were similar among patients with $\mathrm{H}$. pyloriinfected ulcers, NSAID-related ulcers, H. pylori-infected and NSAIDrelated ulcers, and others, either in the superficial epithelium, mononuclear cells of the lamina propria, and mucosal smooth muscle cells $(p>0.05)$. SRF, serum response factor; H. pylori, Helicobacter pylori; NSAID, non-steroidal anti-inflammatory drugs.

but with co-morbidity, with recurrent bleeding but without co-morbidity, and with both recurrent bleeding and co-morbidity $(25.4 \%, 28.4 \%, 75 \%$, and $100 \%$, respectively; $p=0.03)$.

\section{Discussion}

Emerging evidences suggest that the incidences of idiopathic peptic ulcer are increasing in Eastern and Western countries, at $18.8 \%$ and $44 \%$, respectively [4,23-25]. Most of these patients $(\geq 70 \%)$ have co-morbid illnesses and half are severe or life-threatening systemic disorders, such as major organ failure and malignancy $[4,23]$.
These patients have higher risks of ulcer recurrence and bleeding in one-month, 12-month, or 7-year follow-up $[4,5,7,26]$. Although the presence of SRH is a good measure for predicting recurrent bleeding, it cannot predict delayed recurrent bleeding in such patients at risk. It is thus worthy to test whether there is any host background factor other than SRH that can act as a determinant of recurrent bleeding.

Gastric ulcer healing should be assisted with granulation tissues developing at the ulcer base, which consist of proliferating fibroblasts and endothelial cells that restore the lamina propria [12-14,27]. Such healing processes are related to the expression of immediate early genes (eg, c-fos) and muscle-specific genes (eg, smooth muscle $\alpha$-actin, smoothelin), containing serum response element (SRE) to be regulated by SRF [28-31]. By comparing between ulcer tissues and non-ulcer tissues within the same individual, this study is highly original in revealing how SRF intensity can be commonly up-regulated in ulcer tissues than in non-ulcer tissues. Such finding implies that SRF has a potential role in gastric ulcer healing. However, because of varying degrees of SRF up-regulation, there is a need to determine its real clinical significance.

Patients with weak SRF up-regulation in ulcer tissues have significantly higher rates of Forrest classification Ia to IIc SRH in gastric ulcers $(p<0.01)$ and this trend becomes more common with co-morbid illnesses ( $p=$ 0.14) (Table 2). Since SRH and co-morbidities carry higher risks of recurrent bleeding in previous studies $[1,6,19,26,32,33]$, it will be interesting to determine if weak SRF up-regulation on ulcer tissues is associated with recurrent gastric ulcers bleeding.

Aside from serving as significant univariate factors, both the weak up-regulation of SRF and the presence of co-morbidity can be independent risk factors for predicting recurrent gastric ulcer bleeding $(p<0.05)$ (Table 3). As both factors can independently determine recurrent bleeding of gastric ulcers (Table 3 ), it is not surprising to show that their combined effect increases the risk of recurrent gastric ulcer bleeding (Figure 3).

Table 3 The significant univariate analysis and multivariate logistic regression to determine factors associated with recurrent bleeding

\begin{tabular}{|c|c|c|c|}
\hline $\begin{array}{l}\text { Related factors } \\
\text { Univariate analysis }\end{array}$ & Recurrent bleeding rates (\%) & $\begin{array}{l}\text { Odds ratio } \\
(95 \% \mathrm{Cl})\end{array}$ & $\begin{array}{c}P \\
\text { value }^{\dagger}\end{array}$ \\
\hline SRH of Forrest classification la to IIC vs. none & 6.4 vs. 0 & - & 0.06 \\
\hline Comorbidities vs. none & 14.3 vs. 1.7 & $9.92(1.55 \sim 63.49)$ & 0.02 \\
\hline Weak up-regulation of SRF vs. others & 9.8 vs. 1.0 & $10.81(1.17 \sim 99.89)$ & 0.02 \\
\hline Multivariate logistic regression & Coefficient (SE) & $95 \% \mathrm{Cl}$ & $P$ value ${ }^{\ddagger}$ \\
\hline Comorbidities vs. none & $2.29(1.05)$ & $1.25 \sim 77.71$ & 0.03 \\
\hline Weak up-regulation of SRF vs. others & $2.36(1.20)$ & $1.02 \sim 111.07$ & 0.048 \\
\hline
\end{tabular}

$\mathrm{SRH}$ : stigmata of recent hemorrhage; SRF, serum response factor; $\mathrm{Cl}$, Confidence interval; $\mathrm{SE}$, standard error. ${ }^{\dagger} P$ value was assessed by two-tailed Fisher's exact test. ${ }^{\ddagger}$ Indicated the significance of the multivariate logistic regression. 


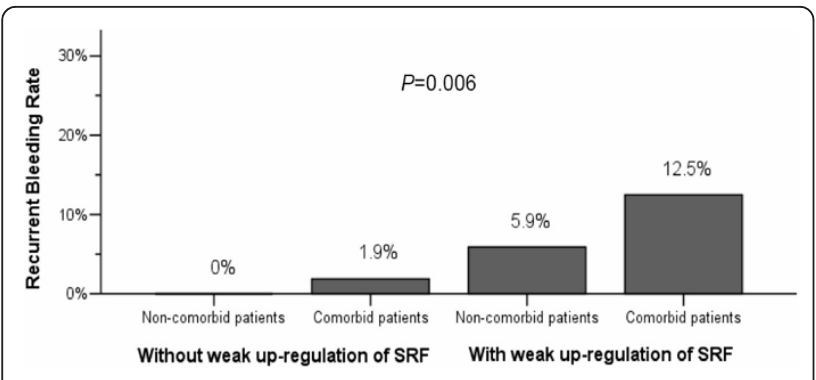

Figure 3 Recurrent bleeding rates of gastric ulcers were increased with weak SRF up-regulation and co-morbidities. SRF, serum response factor.

SRF has potential healing benefits in gastric ulcers, and our result showed weak SRF up-regulation predisposes to increased risk of recurrent gastric ulcer bleeding. SRF makes progress in healing processes such as promotes migration and proliferation of gastric epithelial cells, smooth muscle cells, and endothelial cells $[15,16]$. SRF deficiency inhibits vascular endothelial growth factor (VEGF)-stimulated endothelial cell migration and proliferation and inhibits angiogenesis [34]. Further study are promising to test whether weak SRF up-regulation have a decreased VEGF expression and poor angiogenesis. Moreover, it is promising to conduct further study to validate the correlation between the proliferation index such as proliferating cell nuclear antigen (PCNA) or Ki67 and the SRF expression at the ulcer edge.

SRF is activated by extracellular stimulations such as serum and mitogens through a ternary complex factors-dependent pathway involving the ras-raf-mitogen-activated protein kinase (MAPK)-extracellular signal-regulated kinase (ERK) cascade and other pathways [35]. H. pylori infection activates the SRE-driven c-fos transcription in epithelial cells through the activation of ERK/MAPK cascade [36,37]. It is well known that NSAID suppresses the ERK signaling pathway [38], however, little is known about the effect of NSAID on SRE-driven genes transcription. Nevertheless, our study showed SRF expression on gastric ulcers is not different between patients with $H$. pylori infection and NSAID users (Figure 2). The possible reasons may be whatever the etiology of gastric ulcers is, SRF is triggered and activated by wounding. As $H$. pylori infection and NSAID use are the two major leading etiologies of gastric ulcers, assessing the up-regulation of SRF can be widely applied for most patients.

Although co-morbidity remains an important risk factor of recurrent bleeding of gastric ulcers [1,6,7], the longterm efficacy of oral proton pump inhibitors (PPI) or other gastro-protective agents such as misoprostol to prevent ulcer recurrence and bleeding is uncertain. PPI had been proven to promote gastric epithelial cell proliferation and migration, and can inhibit pro-inflammatory response, which is $\mathrm{pH}$-independent [39-41]. Therefore, the SRF role may be as a possible molecule mechanism and potential therapeutic target for high-risk patients.

Moreover, the other important issue is who will benefit from such therapy. The risk of recurrent bleeding is rather low for those without weak SRF up-regulation. In contrast, the risk increases by 8.29 -fold for those with both co-morbid illnesses and weak up-regulation of SRF (Figure 3). Data here corroborates the assessment of SRF expression in gastric ulcer tissues as meaningful and important in identifying a subset of patients who carry higher risk of recurrent bleeding. For such patients, more aggressive bleeding control such as applying long term oral PPI or improving the weak up-regulation of SRF on gastric ulcers may be mandatory.

Most gastric ulcer bleeding is self-limited, however, a subset of patients have recurrent bleeding. The prognosis factors are old age ( $>60 \mathrm{y} / \mathrm{o})$, comorbidity, large ulcers $(>1.0 \mathrm{~cm}), \mathrm{SRH}$, and others $[1,2,42,43]$. Endoscopic hemostatic therapy prevents recurrent bleeding and mortality [44]. In order to study the correlation of SRF expression and co-morbidity, we enrolled patients who had the similar characteristics of age $(70 \%$ of patients $\geq$ $60 \mathrm{y} / \mathrm{o})$ and ulcer size (62\% of patients had ulcers $\geq 1.0 \mathrm{~cm}$ ) and almost patients $(94.2 \%)$ with Forrest classification Ia to IIb SRH underwent standardized primary endoscopic hemostatic therapy. It may be the reasons why our data show lack of correlation between SRF expression and age, ulcer size, and endoscopic hemostatic therapy.

\section{Conclusions}

In summary, gastric ulcer tissues exert different degrees of SRF up-regulation. The weak up-regulation of SRF on ulcer tissues and the presence of co-morbidities independently increase the risk of recurrent gastric ulcer bleeding. Especially in patients with co-morbidities, improving the up-regulation of SRF may be a potential therapeutic target for preventing recurrent bleeding.

\section{List of abbreviations used}

SRH: Stigmata of recent hemorrhage; SRF: Serum response factor; H. pylori: Helicobacter pylori; NSAID: non-steroidal anti-inflammatory drugs; SRE: Serum response element; VEGF: Vascular endothelial growth factor; PCNA: Proliferating cell nuclear antigen; MAPK: Mitogen-activated protein kinase; ERK: Extracellular signal-regulated kinase; PPI: Proton pump inhibitor.

\section{Acknowledgements}

Financial support: This study was supported in part by research grants from the National Scientific Council, Taiwan (NSC 94-2314-B-006-083 and 972314-B-006-038-MY3), the National Cheng Kung University Hospital grant, Tainan, Taiwan (NCKUH-96-013), and DOH99-TD-C-111-003 from Department of Health, Taiwan.

\section{Author details}

'Institute of Clinical Medicine, Medical College, National Cheng Kung University, Sheng Li Road, Tainan, Taiwan. ${ }^{2}$ Department of Internal Medicine, 
Medical College, National Cheng Kung University, Sheng Li Road,Tainan, Taiwan. ${ }^{3}$ Department of Pathology, Medical College, National Cheng Kung University, Sheng Li Road, Tainan, Taiwan. ${ }^{4}$ Department of Pathology, TonYen General Hospital, Xian Zheng 2ndRoad, Zhubei, Hsinchu, Taiwan. ${ }^{5}$ Institute of Basic Medical Sciences, Medical College, National Cheng Kung University, Sheng Li Road, Tainan, Taiwan.

\section{Authors' contributions}

Guarantor of the article: BSS.

Specific author contributions: HCC and BSS initiated the study and coordinated the conduct of the whole study. HCC wrote and BSS refined the manuscript. HBY reviewed the pathology and SRF expression. HCC and WLC enrolled and followed-up the patients in clinics. YCT and YCY conducted the immunohistochemistry. All authors read and approved the final manuscript.

\section{Authors' information}

Hsiu-Chi Cheng, MD, PhD: Institute of Clinical Medicine, Department of Internal Medicine, Medical College, National Cheng Kung University, Tainan, Taiwan.

Hsiao-Bai Yang, MD: Department of Pathology, Medical College, National Cheng Kung University, Tainan; Department of Pathology, Ton-Yen General Hospital, Hsinchu, Taiwan.

Wei-Lun Chang, MD: Institute of Clinical Medicine, Department of Internal Medicine, Medical College, National Cheng Kung University, Tainan, Taiwan. Yi-Chun Yeh, MS: Institute of Clinical Medicine, Institute of Basic Medical Sciences, Medical College, National Cheng Kung University, Tainan, Taiwan. Yu-Ching Tsai, MD: Institute of Clinical Medicine, Medical College, National Cheng Kung University, Tainan, Taiwan.

Bor-Shyang Sheu, MD: Institute of Clinical Medicine, Department of Internal Medicine, Medical College, National Cheng Kung University, Tainan, Taiwan.

\section{Competing interests}

The authors declare that they have no competing interests.

Received: 18 September 2010 Accepted: 16 March 2011 Published: 16 March 2011

\section{References}

1. Rockall TA, Logan RFA, Devlin HB, Northfield TC: Risk assessment after acute upper gastrointestinal haemorrhage. Gut 1996, 38:316-321.

2. Forrest JA, Finlayson ND, Sherman DJ: Endoscopy in gastrointestinal bleeding. Lancet 1974, 2:394-397.

3. Yang CC, Shin JS, Lin XZ, Hsu PI, Chen KW, Lin CY: The natural history (fading time) of stigmata of recent hemorrhage in peptic ulcer disease. Gastrointest Endosc 1994, 40:562-566.

4. Hung LC, Ching JY, Sung JJ, To KF, Hui AJ, Wong WW, Leong RW, Chan HL, Wu JC, Leung WK, Lee YT, Chung SC, Chan FK: Long-term outcome of Helicobacter pylori-negative idiopathic bleeding ulcers: a prospective cohort study. Gastroenterology 2005, 128:1845-1850.

5. Wong GL, Wong WW, Chan Y, Ching JY, Au K, Hui AJ, Lai LH, Chow DK, Siu DK, Lui YN, Wu JC, To KF, Hung LC, Chan HL, Sung JJ, Chan FK: High incidence of mortality and recurrent bleeding in patients with Helicobacter pylori-negative idiopathic bleeding ulcers. Gastroenterology 2009, 137:525-531.

6. Cheng HC, Chuang SA, Kao YH, Kao AW, Chuang CH, Sheu BS: Increased risk of rebleeding of peptic ulcer bleeding in patients with comorbid illness receiving omeprazole infusion. Hepatogastroenterology 2003, 50:2270-2273.

7. Tseng GY, Fang $C T$, Lin HJ, Yang HB, Tseng GC, Wang PC, Liao PC, Cheng YT, Huang CH: Efficacy of an intravenous proton pump inhibitor after endoscopic therapy with epinephrine injection for peptic ulcer bleeding in patients with uraemia: a case-control study. Aliment Pharmacol Ther 2009, 30:406-413.

8. Greenberg ME, Ziff EB: Stimulation of $3 T 3$ cells induces transcription of the c-fos proto-oncogene. Nature 1984, 311:433-438.

9. Treisman R: Identification of a protein-binding site that mediates transcriptional response of the c-fos gene to serum factors. Cell 1986, 46:567-574.

10. Orr L: Scientists align billion-year-old protein with embryonic heart defects Medical News Today; 2004
11. Chai J, Tarnawski A: Serum response factor: discovery, biochemistry, biological roles and implications for tissue injury healing. J Physiol Pharmacol 2002, 53:147-157.

12. Tarnawski A: Cellular mechanisms of gastric ulcer healing. In The Stomach. Edited by: Domschke W, Konturek SJ. Berlin/New York: Springer-Verlag; 1993:177-192.

13. Tarnawski A: Molecular mechanisms of ulcer healing. Drug News Perspect 2000, 13:158-168.

14. Tarnawski A: Cellular and molecular mechanisms of gastrointestinal ulcer healing. Dig Dis Sci 2005, 50:S24-33.

15. Chai J, Baatar D, Tarnawski A: Serum response factor promotes reepithelialization and muscular structure restoration during gastric ulcer healing. Gastroenterology 2004, 126:1809-1818.

16. Chai J, Norng M, Tarnawski A, Chow J: A critical role of serum response factor in myofibroblast differentiation during experimental oesophageal ulcer healing in rats. Gut 2007, 56:621-630.

17. Sheu BS, Sheu SM, Yang HB, Huang AH, Wu JJ: Host gastric Lewis expression determines the bacterial density of Helicobacter pylori in babA2 genopositive infection. Gut 2003, 52:927-932.

18. Sheu BS, Cheng HC, Kao AW, Wang ST, Yang YY, Yang HB, Wu JJ: Pretreatment with Lactobacillus- and Bifidobacterium-containing yogurt can improve the efficacy of quadruple therapy in eradicating residual Helicobacter pylori infection after failed triple therapy. Am J Clin Nutr 2006, 83:864-869.

19. Sheu BS, Lin CY, Lin XZ, Shiesh SC, Yang HB, Chen CY: Long-term outcome of triple therapy in Helicobacter pylori-related non-ulcer dyspepsia: a prospective controlled assessment. Am J Gastroenterol 1996, 91:441-447.

20. Sung JJ, Mössner J, Barkun A, Kuipers EJ, Lau J, Jensen D, Stuart R, Junghard O, Olsson G: Intravenous esomeprazole for prevention of peptic ulcer re-bleeding: rationale/design of peptic ulcer bleeding study. Aliment Pharmacol Ther 2008, 27:666-677.

21. Sung JJ, Leung WK, Go MY, To KF, Cheng AS, Ng EK, Chan FK: Cyclooxygenase-2 expression in Helicobacter pylori-associated premalignant and malignant gastric lesions. Am J Pathol 2000, 157:729-735.

22. Sheu BS, Yang HB, Sheu SM, Huang AH, Wu JJ: Higher gastric cycloxygenase-2 expression and precancerous change in Helicobacter pylori-infected relatives of gastric cancer patients. Clin Cancer Res 2003, 9:5245-5251

23. Chan HL, Wu JC, Chan FK, Choi CL, Ching JY, Lee YT, Leung WK, Lau JY, Chung SC, Sung JJ: Is non-Helicobacter pylori, non-NSAID peptic ulcer a common cause of upper Gl bleeding? A prospective study of 977 patients. Gastrointest Endosc 2001, 53:438-442.

24. Jyotheeswaran S, Shah AN, Jin HO, Potter GD, Ona FV, Chey WY: Prevalence of Helicobacter pylori in peptic ulcer patients in greater Rochester, NY: is empirical triple therapy justified? Am J Gastroenterol 1998, 93:574-578.

25. Schubert M, MCGuire VAMC, Dewitt JM, Taylor CA: Prospective evaluation of the prevalence of $\mathrm{H}$. pylori in duodenal and gastric ulcer: is its role overstated [abstract]? Gastroenterology 1999, 116:A305.

26. Cheng HC, Kao AW, Chuang CH, Sheu BS: The efficacy of high and low dose intravenous omeprazole in preventing rebleeding for patients with bleeding peptic ulcers and comorbid illnesses. Dig Dis Sci 2005, 50:1194-1201.

27. Martin P: Wound healing-aiming for perfect skin regeneration. Science 1997, 276:75-81

28. Wang JY, Johnson LR: Expression of protooncogenes c-fos and c-myc in healing of gastric mucosal stress ulcers. Am J Physiol 1994, 266: G878-G886.

29. Mack CP, Thompson MM, Lawrenz-Smith S, Owens GK: Smooth muscle alpha-actin CArG elements coordinate formation of a smooth muscle cell-selective, serum response factor-containing activation complex. Circ Res 2000, 86:221-232.

30. Rensen SS, Niessen PM, Long X, Doevendans PA, Miano JM, van Eys GJ: Contribution of serum response factor and myocardin to transcriptional regulation of smoothelins. Cardiovasc Res 2006, 70:136-145.

31. Chai J, Baatar D, Moon W, Tarnawski A: Expression of serum response factor in normal rat gastric mucosa. J Physiol Pharmacol 2002, 53:289-294

32. Cheng HC, Chang WL, Yeh YC, Chen WY, Tsai YC, Sheu BS: Seven-day intravenous low-dose omeprazole infusion reduces peptic ulcer 
rebleeding for patients with comorbidities. Gastointest Endosc 2009, 70:433-439.

33. Zaragoza AM, Tenías JM, Llorente MJ, Alborch A: Prognostic factors in gastrointestinal bleeding due to peptic ulcer: construction of a predictive model. J Clin Gastroenterol 2008, 42:786-790.

34. Chai JY, Jones MK, Tarnawski A: Serum response factor is a critical requirement for VEGF signaling in endothelial cells and VEGF-induced angiogenesis. FASEB J 2004, 18:1264-1266.

35. Johansen FE, Prywes R: Two pathways for serum regulation of the c-fos serum response element require specific sequence elements and a minimal domain of serum response factor. Mol Cell Biol 1994, 14:5920-5928

36. Mitsuno Y, Maeda S, Yoshida H, Hirata Y, Ogura K, Akanuma M, Kawabe T, Shiratori Y, Omata M: Helicobacter pylori activates the proto-oncogene c-fos through SRE transactivation. Biochem Biophys Res Commun 2002, 291:868-874.

37. Hirata Y, Maeda S, Mitsuno Y, Tateishi K, Yanai A, Akanuma M, Yoshida H, Kawabe T, Shiratori Y, Omata M: Helicobacter pylori CagA protein activates serum response element-driven transcription independently of tyrosine phosphorylation. Gastroenterology 2002, 123:1962-1971.

38. Pan MR, Chang HC, Hung WC: Non-steroidal anti-inflammatory drugs suppress the ERK signaling pathway via block of Ras/c-Raf interaction and activation of MAP kinase phosphatases. Cell Signal 2008, 20:1134-1141.

39. Suzuki H, Masaoka T, Minegishi Y, Motosugi Y, Miura S, Ishii H: Lansoprazole promotes gastric mucosal cell proliferation and migration by activating p44/p42 mitogen-activated protein kinase. Wound Rep Reg 2004, 12:93-99.

40. Ng KM, Cho CH, Chang FY, Luo JC, Lin HC, Lin HY, Chi CW, Lee SD: Omeprazole promotes gastric epithelial cell migration. J Pharm Pharmacol 2008, 60:655-660.

41. Handa O, Yoshida N, Fujita N, Tanaka Y, Ueda M, Takagi T, Kokura S, Naito Y, Okanoue T, Yoshikawa T: Molecular mechanisms involved in antiinflammatory effects of proton pump inhibitors. Inflamm Res 2006, 55:476-480.

42. Gilinsky NH: Peptic ulcer disease in the elderly. Scand J Gastroenterol 1988, 23(Suppl 146):191-200.

43. Branicki FJ, Coleman SY, Fok PJ, Pritchett CJ, Fan ST, Lai EC, Mok FP, Cheung WL, Lau PW, Tuen HH, Lam SK, Hui WM, Ng MM, Lam DK, Tse MC, Tang AP, Wong J: Bleeding peptic ulcer: A prospective evaluation of risk factors for rebleeding and mortality. World J Surg 1990, 14:262-269.

44. Cook DJ, Guyatt GH, Salena BJ, Laine LA: Endoscopic therapy for acute nonvariceal upper gastrointestinal hemorrhage: A meta-analysis. Gastroenterology 1992, 102:139-148.

Pre-publication history

The pre-publication history for this paper can be accessed here: http://www.biomedcentral.com/1471-230X/11/24/prepub

doi:10.1186/1471-230X-11-24

Cite this article as: Cheng et al:: Weak up-regulation of serum response factor in gastric ulcers in patients with co-morbidities is associated with increased risk of recurrent bleeding. BMC Gastroenterology 2011 11:24.

\section{Submit your next manuscript to BioMed Central and take full advantage of:}

- Convenient online submission

- Thorough peer review

- No space constraints or color figure charges

- Immediate publication on acceptance

- Inclusion in PubMed, CAS, Scopus and Google Scholar

- Research which is freely available for redistribution

Submit your manuscript at www.biomedcentral.com/submit
Biomed Central 